IRSH 6I (2016), pp. 223-250 doi:10.10I7/S00208590I60002 I 3

(C) 2016 Internationaal Instituut voor Sociale Geschiedenis. This is an Open Access article, distributed under the terms of the Creative Commons Attribution licence (http://creativecommons.org/licenses/by/4.o/), which permits unrestricted re-use, distribution, and reproduction in any medium, provided the original work is properly cited.

\title{
Moralizing Postcolonial Consumer Society: Fair Trade in the Netherlands, 1964-1997*
}

\author{
PETER VAN DAM \\ University of Amsterdam, Faculty of Humanities \\ Kloveniersburgwal 48, IOI2 CX Amsterdam, The Netherlands \\ E-mail: p.h.vandam@uva.nl
}

AвSTRACT: Decolonization challenged people across the globe to define their place in a new postcolonial order. This challenge was felt in international political and economic affairs, but it also affected daily lives across the globe. The history of fair trade activism as seen from the Netherlands highlights how citizens in the North grappled to position themselves in a postcolonial consumer society. Interventions by fair trade activists connected debates about the morals of their society to the consequences of decolonization. They reacted to the imbalances of the global market in the wake of decolonization, joining critics from the South in demanding more equitable global relations. It was around this issue of "fair trade" that a transnational coalition of moderate and more radical activists emerged after the r960s. This coalition held widely dissimilar views regarding the politics of the left and the use of consumer activism. The analysis of their interventions demonstrates that during the postwar era attempts at transforming the global market were inextricably interwoven with visions of a postcolonial order.

"Modern capitalism has elaborated and realized - in particular countries but with the intention of embracing the whole world - the ideologies of the 'affluent society' or the 'consumer society'”, the Argentinian labour leader Emilio Maspéro told representatives of about sixty European Third World groups gathered in Egmond aan Zee in April 1970. This ideology could

* A draft of this article was presented as part of the "Mass consumption contested" session at the ESSHC in Vienna, 24 April 20I4. I would like to thank the participants at that session, as well as the anonymous reviewers and the editors of the IRSH for their insightful comments on earlier versions of this article. The article presents results from the research project "Moralising the global market. Fair trade in post-war Dutch history", which is funded by the Netherlands Organization for Scientific Research. 
be summed up, he continued, simply as "consume and hold your tongue". ${ }^{\text {. }}$ While the citizens of the industrialized nations were thus bound by golden chains, people in the Third World suffered under the oppression of capitalist imperialism. There was hope, however: "The fight of the poor countries would be very long, uncertain and success would be even more difficult, if at the same time we strike with all our strength the tail of the serpent of imperialism and of international capitalism, you, in the rich countries do not strike with the same strength its head to destroy it totally."

Not all participants present in Egmond aan Zee were as adamant in their rejection of consumer society. The dominant course of action promoted among them was to pressure the economic and political elites of the industrialized nations to structurally improve the situation of the Third World and raise awareness of the ways in which the inhabitants of these countries were part of an unjust system. ${ }^{3}$ International consumer action was considered a prime strategy to this end. Among the handful of practical resolutions adopted by the assembly was the proposal to set up an international cane sugar campaign. ${ }^{4}$ It would take its cue from the existing campaign in the Netherlands, which had started in I968. By urging consumers to buy cane sugar instead of the beet sugar produced within the European Economic Community, it called attention to the unequal global trading structures that disadvantaged developing countries. The transnational history of fair trade activism as seen from the Netherlands highlights how decolonization challenged citizens to position themselves in a postcolonial consumer society. Around the issue of "fair trade", a transnational coalition of moderate and more radical activists emerged. These activists held disparate views regarding the politics of the left and the uses of consumer activism. Their continued cooperation revolving around the responsibility of Northern consumers towards Southern producers underlines how, during the postwar era, attempts to transform the global market were inextricably interwoven with visions of a postcolonial world.

\section{CONTESTING POSTCOLONIAL CONSUMER SOCIETY}

Maspéro's call for European citizen-consumers to come to the aid of developing countries highlights the connection between two crucial strands of European postwar history, namely the rise of a society in which citizens self-consciously defined themselves as consumers and the advent of

I. Henk Biersteker and Huub Coppens, Towards Internationalised Development Action: Report of the International Working-Congress of Action-Groups on International Development (The Hague, 1971), p. 64.

2. Ibid., p. 68.

3. Henk Biersteker, "Kongres van aktiegroepen", Sjaloom: Maandblad, 7 (1970), pp. 4, 6-7.

4. Biersteker and Coppens, Towards Internationalised Development Action, pp. 87-91, 105. 
a postcolonial era. During the I950s and I960s, expenditure on new items of mass consumption such as refrigerators, washing machines, televisions, and cars reached unprecedented levels. ${ }^{5}$ Moral concerns over consumption had frequently surfaced in earlier periods, too, but the postwar increase in the material standard of living was accompanied by a new outlook on consumption. ${ }^{6}$ Immediately after World War II, citizens across Europe expected their governments to provide them with social security rather than just social insurance. ${ }^{7}$ In addition to the social security arrangements that sprang up across the continent during the years of postwar reconstruction, a new emphasis on the importance of individual consumption emerged. Citizens had more than just the right to security. As consumers, they had the right to affluence. ${ }^{8}$ Consumer activism had played a pivotal role in bringing about this change, and transnational consumer organizations continued to attempt to influence the shape in which societies were being built in the name of consumers. ${ }^{9}$

While Western Europe witnessed unparalleled economic growth from the I950s onwards, it lost its colonial hegemony. In I945, through its claim to Southeast Asian and Caribbean territories, the Netherlands still imagined itself to be an important colonial power. As in fellow European countries such as France and the United Kingdom, in the postwar years the self-image of the Dutch as a colonial power was shattered by the movement for decolonization, which encompassed the independence of Indonesia, the Dutch colonial "crown jewel”, in i949. In many ways, decolonization was connected to the spectacular economic recovery. European colonial aspirations had been a constant source of friction with the United States. Their demise forged a closer alliance against communism, which was accompanied by the heightened importance of the notion of free markets and free consumers. It also united Americans and Western Europeans in their efforts to integrate the newly independent states in Africa and Asia

5. Dudley Baines, Neil Cummins, and Max-Stephan Schulze, "Population and Living Standards, 1945-2005", in Stephen Broadberry and Kevin H. O’Rourke (eds), The Cambridge Economic History of Modern Europe. Volume 2: I 870 to the Present (Cambridge, 2010), pp. 390-420.

6. An important example of moral concern about consumption in the context of economic relations between the North and the South can be found in the targeting of sugar produced on plantations by abolitionists. See Ulbe Bosma, The Sugar Plantation in India and Indonesia: Industrial Production, $1770-2010$ (Cambridge, 2013), pp. 60-6I.

7. Aiqun $\mathrm{Hu}$ and Patrick Manning, "The Global Social Insurance Movement since the I880s", Journal of Global History, 5: (2010), pp. I25-148, I4I; Tony Judt, Postwar: A History of Europe since 1945 (New York, 2005), pp. 72-76.

8. Claudius Torp, Wachstum, Sicherheit, Moral: Politische Legitimationen des Konsums im 20. Jabrbundert (Göttingen, 2012), pp. 92-108; Sheryl Kroen, "A Political History of the Consumer", The Historical Journal, 47:3 (2004), pp. 709-736.

9. Lawrence B. Glickman, Buying Power: A History of Consumer Activism in America (Chicago, 2009); Matthew Hilton, Prosperity for All: Consumer Activism in an Era of Globalization (Ithaca, 2009). 
into the Western free market. This integration benefited the former much more than the latter, however: in order to become part of the Western economic infrastructure and to receive loans from the World Bank or the International Monetary Fund, newcomers had to adopt market-oriented policies and depended on US political goodwill and economic policy through their linkage to the US dollar and the influence of the US government within international economic institutions. ${ }^{10}$ Especially during the 1960s, the economic balance seemed to favour Western countries. Although export commodities from Africa, Asia, and South America fuelled European industry, their prices gradually fell in relation to the prices of industrial products.

The shared economic disadvantage of the developing countries paired with their aversion to Western political dominance created a sense of solidarity among them. This solidarity was translated into concrete political initiatives: building on a tradition of anti-colonial cooperation, a group of underprivileged countries presented themselves as a political factor to be reckoned with. Due to their united stance on many issues, they managed to translate their demand for an international approach to the issue into the organization of the UN Conference on Trade and Development (UNCTAD), first held in Geneva in 1964. ${ }^{\mathrm{II}}$ The UNCTAD conferences - a second was held in 1968 in New Delhi - became highly publicized events, at which Northern countries showed little inclination to accommodate the developing countries. As a result, opposition to the policies of the industrialized states grew not just among the disadvantaged countries, but also among those citizens of industrialized nations who were sensitive to the criticism formulated by the challengers of Northern dominance.

Decolonization forced people in the North to reflect on their colonial past and on the consequences of decolonization for a new outlook on the world. ${ }^{12}$ Many civic organizations felt the pressure to respond: international trade unions deemed it of crucial importance to find members in the newly independent states. ${ }^{13}$ Churches redefined their outlook on the world, from the notion of the "old" church of the West with "new" churches in other parts of the world towards the notion of a truly global church, in which Western churches were not just the equals of churches

Io. Odd Arne Westad, The Global Cold War: Third World Interventions and the Making of Our Times (Cambridge, 2005), pp. 27, I 52-I 57.

I I. Giuliano Garavini, "The Colonies Strike Back: The Impact of the Third World on Western Europe, I968-1975", Contemporary European History, I6:3 (2007), pp. 299-3 19; Vijay Prashad, The Darker Nations: A People's History of the Third World (New York, 2007); Mark Atwood Lawrence, "The Rise and Fall of Nonalignment”, in Robert J. McMahon (ed.), The Cold War in the Third World (New York, 2013), pp. 139-155.

I 2. Esther Helena Arens, “'Mission Interrupted?' Die Diskussion über die Dekolonisierung in den Niederlanden”, Archiv für Sozialgeschichte, 48 (2008), pp. I33-1 54.

13. Peter van Dam, Religion und Zivilgesellschaft: Christliche Traditionen in der Niederländischen und Deutschen Arbeiterbewegung (1945-1980) (Münster, 2010), pp. I87-189. 
on other continents, but were also inspired by them to reconsider their own positions. ${ }^{14}$ Most visibly, many different intellectual and youth groups discovered the Third World as a source of inspiration in the struggles for their own liberation. ${ }^{\text {Is }}$

It was in these circumstances that the movement for fair trade emerged during the I960s through a series of attempts to promote global equity. By examining the transnationally entangled activities of the pioneering and transnationally influential fair trade movement in the Netherlands, this article will be able to shed light on the dynamics of this transnational social movement. ${ }^{16}$ It is hard to classify this movement within existing categories of social movement research. Fair trade is often portrayed as part of a broader Third World movement. ${ }^{17}$ Although groups of fair trade activists did indeed identify themselves with the Third World movement, especially during the I970s and early I 980 s, this perspective tends to ignore the markedly heterogeneous composition of the movement within that period and beyond. Four currents can be discerned: activists concerned with issues of development, religious - above all ecumenical groups, proponents of international solidarity with Third World countries, and youth organizations. It is often impossible to clearly distinguish these currents. For example, many ecumenical groups were deeply involved in issues of development and international solidarity. Labelling the fair trade movement a "new social movement" is equally problematic.

I4. Sebastian Tripp, "Die Weltkirche vor Ort. Die Globalisierung der Kirchen und die Entstehung Christlicher 'Dritte-Welt'-Gruppen”, in Wilhelm Damberg (ed.), Soziale Strukturen und Semantiken des Religiösen im Wandel. Transformationen in der Bundesrepublik Deutschland 1949-1989 (Essen, 20II), pp. I23-136; James C. Kennedy, "Protestant Ecclesiastical Internationals", in Abigail Green and Vincent Viaene (eds), Religious Internationals in the Modern World: Globalization and Faith Communities since 1750 (Houndmills, 201 2), pp. 292-3 I 8.

I 5. Samantha Christiansen and Zachary A. Scarlett (eds), The Third World in the Global I960s (New York, 2013); Christoph Kalter, Die Entdeckung der Dritten Welt. Dekolonisierung und neue radikale Linke in Frankreich (Frankfurt, 20I I); Niek Pas, Aan de wieg van het niewwe Nederland. Nederland en de Algerijnse oorlog 1954-I962 (Amsterdam, 2008); Maarten Kuitenbrouwer, De ontdekking van de Derde Wereld. Beeldvorming en beleid in Nederland, 1950-I 990 (The Hague, I994), pp. I-2 I.

I6. Erik Swyngedouw, "Neither Global nor Local: 'Glocalization' and the Politics of Scale”, in Kevin R. Cox (ed.), Spaces of Globalization: Reasserting the Power of the Local (New York, I997), pp. I37-I64; Saskia Sassen, "The Many Scales of the Global: Implications for Theory and for Politics", in Revathi Krishnaswamy and John C. Hawley (eds), The Postcolonial and the Global (Minneapolis, 2008), pp. 82-93; Dieter Rucht, “The Transnationalization of Social Movements: Trends, Causes, Problems”, in Donatella Della Porta, Hanspeter Kriesi, and Dieter Rucht (eds), Social Movements in a Globalising World (Houndmills, 1999), pp. 206-222.

17. Hans Beerends, De Derde Wereldbeweging. Geschiedenis en toekomst (The Hague, I992); Claudia Olejniczak, Die Dritte-Welt-Bewegung in Deutschland. Konzeptionelle und organisatorische Strukturmerkmale einer neuen sozialen Bewegung (Wiesbaden, I999); Konrad Kuhn, Entwicklungspolitische Solidarität. Die Dritte-Welt-Bewegung in der Schweiz zwischen Kritik und Politik (1975-1992) (Zurich, 201 I). 
Indeed, fair trade activists often rhetorically distanced themselves from "old" social movements. ${ }^{18}$ In practice, the movement bridged supposed gaps between "old" and "new" movements to a remarkable extent, both in terms of its membership and regarding the organizations it attempted to cooperate with. ${ }^{19}$

Alternatively, historians such as Frank Trentmann and Lawrence Glickman have presented fair trade as part of a longer tradition of consumer activism. ${ }^{20}$ The repertoire of the movement has indeed continually included strategies related to consumer activism such as boycotts and buycotts, which deserve to be explored as part of a longer tradition of consumer activism. However, the range of initiatives employed by the movement extends well beyond consumer activism, including, for example, protest rallies, informational campaigns, and political lobbying. ${ }^{2 \mathrm{I}}$ The "trade" in fair trade has not always been directly related to acts of individual consumption. It could also pertain to relations between states, between states and companies, or between producers and companies, without directly involving consumers.

Above all, these diverse attempts at achieving global equity are united by their implicit and explicit responses to the challenges posed by the advent of a postcolonial world. ${ }^{22}$ Fair trade can therefore fruitfully be regarded as postcolonial activism. Such a perspective accounts for the decisive role of actors from the South in shaping the movement, which arose within the context of a global order destabilized by the consequences of decolonization. As noted, it took its cue from the unfulfilled demands of people in disadvantaged countries, voiced at international conferences, through publications, and in many personal encounters. The postcolonial perspective can also account for the frequent explicit references to a colonial legacy formulated by the movement. Fair trade activists presented strategies to overcome dependency and achieve global equality as attempts to complete decolonization. Because of their preoccupation with overcoming

I8. Pem Rutgers-Sluijter, Arie Kuiper, and Dick Scherpenzeel, "Wat kunnen particuliere organisaties voor ontwikkelingssamenwerking bijdragen aan 'mentaliteitsverandering'?", ViceVersa, 5:20 (1972), pp. 3-1 3 .

19. Peter van Dam, "Handel im Tempel? Fair Trade und Kirchen in den Niederlanden seit 1945", in Wilhelm Damberg and Traugott Jähnichen (eds), Nene Soziale Bewegungen als Herausforderung sozialkirchlichen Handelns (Stuttgart, 201 5), pp. 279-296; Matthew Anderson, A History of Fair Trade in Contemporary Britain: From Civil Society Campaigns to Corporate Compliance (Houndmills, 2015), pp. 23-66; Ruben Quaas, Fair Trade: Eine global-lokale Geschichte am Beispiel des Kaffees (Cologne, 2015), pp. 35-40.

20. Frank Trentmann, "Before 'Fair Trade': Empire, Free Trade, and the Moral Economies of Food in the Modern World", Environment and Planning D: Society and Space, 25 (2007), pp. 1079-I 102; Glickman, Buying Power.

2 I. Hans Beerends et al., Anders nog iets? (Amersfoort, 1979).

22. Bill Schwarz, "Actually Existing Postcolonialism", Radical Philosophy, 104 (2000), pp. 16-24. 
the differences between North and South, these attempts were often expressed in the language of development. They were primarily directed at economic development, but more often than not they were also aimed at social and political development.

Regarding fair trade as a form of postcolonial activism finally points towards the transnational orientation of the movement, which pertains both to its concern with the Global South, but also to the transnational character of the movement in the North. The fair trade movement was markedly transnational in terms of organization. The activists' activities were often organized not nationally, but locally, regionally, or internationally, and regularly took aim at European and international politics. Therefore, the history of fair trade explicitly questions the reach of a national perspective. ${ }^{23}$ The history of fair trade activism demonstrates how decolonization did not just influence international politics and the global economy, but also led citizens across the world to reconsider their views of a moral economy. Their attempts to arrive at an equitable postcolonial world order provide an important window onto the contested nature of postcolonial globalization. ${ }^{24}$

\section{TRADE, NOT AID (1964-1973)}

The origin of the movement for fair trade can be situated at the point where providing aid was replaced by enabling trade. The transformation was closely connected to the ongoing process of decolonization, during which developing countries and their supporters in Northern countries argued that economically disadvantaged producers should not be treated as objects of sympathy but as equal partners. This approach was based on a moderate critique of postcolonial global relations, which emphasized inequalities that could be overcome through equitable relations and reforms to the global trading mechanisms. During these early years of fair trade activism, then, moderate activists dominated the movement, although more radical voices could certainly be heard.

The shift towards regarding producers from the South as equal partners that ought to be empowered can be observed first-hand in the history of SOS Wereldhandel, a Dutch organization founded in 1959 by members of a Catholic youth group in Kerkrade. SOS started out providing aid and ended up as one of the main importers of fair trade products in Europe.

23. Pierre-Yves Saunier, Transnational History (Basingstoke, 2013); Philipp Gassert, "Transnationale Geschichte", Version 2.0, Docupedia-Zeitgeschichte, 20I2, available at: http://docupedia. de/zg/Transnationale_Geschichte_Version_2.0_Philipp_Gassert, last accessed 9 February 20I 5; Peter van Dam, "Vervlochten geschiedenis. Hoe histoire croisée de natiestaat bedwingt", Tijdschrift voor Geschiedenis, I $25:$ I (2012), pp. 96-109.

24. Peter van Dam, "The Limits of a Success Story: Fair Trade and the History of Postcolonial Globalization”, Comparativ, 25:I (2015), pp. 62-77. 
After a successful attempt to collect money to provide the Sicilian population with powdered milk in 1959, a group of young Catholics, headed by the local politician Paul Meijs, founded the organization to coordinate similar but more ambitious activities in the future. ${ }^{25}$ In trying to raise money, SOS members employed a variety of methods. Anyone listed in the phonebook could expect a telephone call from one of its fundraisers, "emergency chests" were placed in churches for churchgoers to make a contribution in kind, and people received letters in the post calling on them to make even a small donation.

Soon, members of SOS shifted their focus from providing emergency relief to providing financial assistance to humanitarian projects. In 1962, they launched a campaign to raise three million guilders (about eight million euros in today's money) to support a number of projects, including the construction of a hospital and a sanatorium and the expansion of Catholic schooling. ${ }^{26}$ In line with attempts at modernization, which predominated in development assistance during the I960s, SOS stated that the projects being supported were intended to become self-supporting after receiving an initial loan or grant. ${ }^{27}$ To locate suitable projects, SOS worked closely with Catholic organizations. Misereor, a German Catholic aid organization in Aachen, was a particularly important partner because of its proximity to Kerkrade and its many contacts in developing countries. Noticing how many of the projects they supported were unable to find enough buyers for their produce, SOS and Misereor launched attempts to sell their produce to customers in Germany, Belgium, and the Netherlands. The money raised by selling these products would be used to cover the costs of importing and selling the products. Any profits would be channelled back to the producers, who could then expand capacity or set up development projects themselves. ${ }^{28}$

As it made this shift towards stressing the goal of producer autonomy in developing countries around 1967 , SOS focused on selling artisanal produce. According to the organization, this had the added benefit of bringing European people into contact with artistic expressions of people from developing countries. Above all, though, these products would create business opportunities in developing countries that would not threaten the livelihood of European producers. ${ }^{29}$ Notably, around the same time, Oxfam set up the trading company Helping by Selling. Helping by Selling

25. Paul Arnold, “'Went v'r jet dunt dan dunt v'r 't jot!' De geschiedenis van de Kerkraadse Stichting Steun Onderontwikkelde Streken, later S.O.S. Wereldhandel, 1959-1986”, Studies over de Sociaal-Economische Geschiedenis van Limburg, 46 (200I), pp. 3-43.

26. "Stichting S.O.S. start acties voor missie in Nyassaland", Limburgs Dagblad, 6 December 1962.

27. "SOS streeft naar ontwikkelingshulp op zakelijke basis", Ibid., is September I967.

28. Quaas, Fair Trade, pp. 63-65.

29. "SOS streeft naar ontwikkelingshulp op zakelijke basis". 
aimed at importing artisanal products from developing countries. These would then be sold in Oxfam shops throughout the UK. Any profits were channelled to Oxfam's budget for international development. Arguing in favour of this kind of trade along the same lines as SOS and Misereor, Helping by Selling additionally stressed that artisanal products would increase employment in developing countries. ${ }^{30}$ The ventures by SOS and Misereor and by Oxfam took up the call for "trade not aid" associated with the first United Nations Development Decade. Trade was regarded as both a practical means to empower producers and to raise money for development.

Within just four years, SOS had radically changed its tone. In a policy document written by Paul Meijs, SOS argued that the "politics of self-interest" had neglected the interests of developing countries for too long. Aid could be substituted by trade only if Western countries drastically changed their policies, such as subsidizing European agricultural products and erecting trade barriers to keep out similar products from developing countries. ${ }^{3 \mathrm{I}}$ Although SOS maintained a focus on trade with developing countries, it no longer exclusively emphasized empowering producers in these countries. According to this new policy, changes to the structure of the global market were necessary in order to create a more equitable relationship between the South and the North.

What had caused this striking change? The pressure exerted by those developing countries that had united to challenge the trade policies instituted by Northern countries had brought about a strange success. Precisely because representatives of these nations had made no significant concessions, critical Northern reporters at the UNCTAD conferences and sympathetic observers at home had sought to express their support for the cause of the South. In 1964, the journalist Henk van Randwijk condemned the egoism of Northern countries during the UNCTAD conference in Geneva. Those countries were building a "great society", but only for themselves, skewing the global marketplace in their favour and then urging developing countries to do something about their own fate. ${ }^{32}$ Similarly frustrated with the results of the second UNCTAD conference in New Delhi in 1968, the journalist Dick Scherpenzeel concluded that any change had to start with a different mentality among Western citizens. Only if a larger part of the electorate saw the need for a change in international trade policies would their elected representatives follow. ${ }^{33}$ Back in the

30. Anderson, A History of Fair Trade, pp. 26-28.

31. Paul Meijs, Ontwikkelingsstrategie van S.O.S. voor de periode 1970-1980 (Kerkrade, I97I), pp. I-2.

32. Henk van Randwijk, "Twee redevoeringen, die op de Wereldhandelsconferentie niet werden uitgesproken”, Maatstaf, I 2:3 (I964), pp. 2 I 2-232.

33. Dick Scherpenzeel, Trieste balans. Beschowwingen van Dick Scherpenzeel over ontwikkelingssamenwerking, Afrika en de Derde Wereld, 1965-1973 (The Hague, I976), pp. 68-72. 
Netherlands, Scherpenzeel urged like-minded people to present initiatives to raise awareness among the population about how Western representatives perpetuated global inequality.

A successful initiative to raise awareness about unfair trade was launched in the autumn of 1968. The "I968 Cane Sugar Campaign" (Rietsuikeractie 1968) announced that, in light of the failure of recent conferences on world trade to improve the situation of developing countries, it was launching a campaign to sell and promote cane sugar. This way, they would confront the public with the message that the European Economic Community was using tariffs to prevent cane sugar from developing countries being sold and at the same time supporting the production of beet sugar in Europe through agricultural subsidies. ${ }^{34}$ The cane sugar campaign promoted a reform of the global market in favour of developing countries by distributing information on the global sugar trade, by attracting media attention, and by lobbying politicians directly.

Buying and selling cane sugar had a twofold importance. On the one hand, trading cane sugar symbolically drew attention to the structure of a global market. At the same time, increasing cane sugar sales was regarded by participants as a practical way of financially supporting cane sugar producers in developing countries, or as a practical first step in restructuring the global market in favour of developing countries producing cane sugar. However, campaign supporters differed considerably in terms of the strategy for achieving a fair global market. Some favoured an international division of labour, as proposed by the economist Jan Tinbergen, who had argued for the international coordination of production to achieve a more balanced global economy. Others drew on the ideas of economists such as Gunnar Myrdal and Raúl Prebisch, who had criticized the vicious circle of dependency of developing countries on the industrialized world. Instead, they wanted to achieve a more independent position for developing countries by improving their international trading position for the commodities they currently exported and by increasing their own industrial production. $^{35}$

Accommodating these different views within a single campaign, the campaign managed to attract considerable public attention. The campaign committee published extensive documentation on the subject, which in turn provoked a massive response on the part of the Dutch sugar industry: while the two publications sponsored by the campaign peddled over 40,000 copies, the Dutch Sugar Union sold 50,000 copies of a publication countering the critique of beet sugar, and distributed another I 30,000 for free.

34. Perscommuniqué Rietsuikeraktie 1968, 27 September 1968, personal archive Paul van Tongeren.

35. Garavini, “The Colonies Strike Back”, p. 3 I4; Kuitenbrouwer, Ontdekking van de Derde Wereld, pp. I 5-I 8. 
The campaign turned the distant topic of international trade into something that could be discussed locally and had clear implications for daily life and national politics. The possibility to transform a global issue into something that could be addressed by specific local action appealed to a diverse coalition of youth groups, sympathetic church members, and politicians, most of them with leftist sympathies. Many local groups followed up the recommendations made by the campaign committee to take action. Suggestions included buying cane sugar individually and through the organizations of which one was a member, asking grocers to sell it in their stores, writing in local papers about the issue, hosting discussions and exhibitions, and distributing literature and posters advertising the campaign ${ }^{36}$ The campaign temporarily bridged the divide not only between the old and the new left, but also between groups on the left and other citizens concerned about the fate of developing countries.

Debates about European sugar policy dealt not just implicitly with the legacy of decolonization presented in the demands of developing countries for trade reforms. Critics and proponents of European sugar policy alike explicitly invoked the context of decolonization to support their claims. Attempts to promote beet sugar over cane sugar were presented as a way to secure independence from the production by former colonies, which, ironically, depended on trading cane sugar because their former colonial masters had forced them to. ${ }^{37}$ On the other hand, the engineer J.J. Eshuis, on behalf of the Dutch sugar industry, warned against the kind of misplaced idealism that the Americans had used to force the Netherlands to relinquish New Guinea in 1963. Instead of Dutch attempts to educate the local population so that, one day, they would be able to govern themselves, Indonesia took control. "The historian will have to judge whether this has been a blessing for the country", Eshuis warned ominously of the future of New Guinea as part of Indonesia, another country the Dutch had claimed they would have to educate before it was fit to rule autonomously, he could have added..$^{8}$

After its initial success, the cane sugar campaign soon encountered difficulty. The international congress of Third World groups that had gathered in Egmond aan Zee in I 970 was not unanimously enthusiastic about it, even though it ultimately recommended setting up an international equivalent to the Dutch initiative. Participants remarked on the dismal circumstances of workers in the cane sugar industry and on the risk of beet sugar being dumped on the world market once it had been replaced by significant amounts of cane sugar in Europe. Others were concerned by the

36. Eduard van Hengel, Suikerraffinement. Rietsuikeraktie I968 (Amsterdam, 1968), p. 34.

37. Piet Reckman, Riet. Het verhaal van de suiker (Baarn, I969).

38. J.J. Eshuis, F.C. de Jong, and G.J. de Gilde, Suiker en de ontwikkelingslanden. Bietsuikerproduktie een gezonde zaak (Rotterdam, 1968), p. 8. 
incentive it provided to develop monocultures, which, in the long run, would increase dependency on Western markets. ${ }^{39}$

In the end, hopes for a coordinated international campaign were frustrated not just because of the doubts of many activists, but also because of local and national differences. The Dutch campaign was followed up quite successfully across Europe, but attempts to combine different initiatives into a European campaign fell short. In the United Kingdom, the World Development Movement initiated a sugar campaign much earlier than agreed, in order to still be able to influence the debate about sugar agreements with former colonies once the UK joined the European Economic Community. In West Germany, cane sugar was hard to come by, while many Third World groups had already turned to other models for action by the time some local groups took up the initiative. ${ }^{40}$ Similarly, attempts to set up sugar campaigns in Belgium, Denmark, France, and Italy were quietly abandoned..$^{4 \mathrm{I}}$ In fact, even while the cane sugar campaign was being discussed as a model for international action, many Dutch sympathizers had started to explore new ways to promote the cause of developing countries, which centred on the notion of the "world shop".

\section{WORKING TOWARDS LIBERATION (1973-1984)}

The first world shop opened in 1969 in the small Dutch town of Breukelen. A local mathematics teacher, Johan Derks, started to sell products imported by SOS from his living room. Soon, others joined him. Together, they obtained permission to open up a shop in an abandoned building, which was renovated for them by a Catholic youth group. The idea was quickly taken up by those who had also promoted the cane sugar campaign. For example, during the yearly "peace weeks" hosted by the Catholic peace movement Pax Christi a publication urging participants to take action at home suggested that founding a world shop might be a way to take responsibility for the state of the world: "It is easy to forget that the voterconsumer in rich countries is also personally responsible for the violence

39. Biersteker, "Kongres van aktiegroepen", p. 6.

40. Piet Reckman, Rohr. Die Geschichte des Zuckers (Nuremberg, 1970); Hans-Eckehard Bahr (ed.), Politisierung des Alltags. Gesellschaftliche Bedingungen des Friedens (Darmstadt, 1972); Poster “EWG-Rohrzuckerkampagne '7 I", personal archive Paul van Tongeren; Bastian Hein, Die Westdeutschen und die Dritte Welt. Entwicklungspolitik und Entwicklungsdienste zwischen Reform und Revolte 1959-I974 (Munich, 2005), p. I45; Quaas, Fair Trade, pp. 84-86.

4I. Paul van Tongeren, "Rietsuikeractie slaat ook in andere landen aan", Groene Amsterdammer, 2 January 1970, p. 4; Clifford Longley, "How the Sugar Lobby is Preparing for Battle", The Times, is February I97I, p. I2; Werner Gebert, Wirken Sie mit an der Planung und Vorbereitung der internationalen Robrzuckerkampagne (Freiburg, 197I). 
waged in the world. [...] We have to look at ourselves, at the structures in our own rich North, at the small group that decides here and there." ${ }^{42}$

This stress on the need for changes within the West itself reflected a move towards a more radical politics within the fair trade movement. This move was clearly present in the objectives formulated by the national foundation of world shops in 1970: "The primary objective of the world shops is to expose and attack the economic and political structures that stand in the way of a just global division of labour and income." 43 These shops accordingly had to serve as campaign centres that would not just sell products to expose unfair trade structures and support people in developing countries, but also coordinate boycotts, collect goods to send to freedom fighters, and confront local communities with information about unjust circumstances across the world. ${ }^{44}$ These objectives were mirrored in the advice provided on furnishing a world shop: ideally, the shop would offer not just the possibility to obtain goods and information, but also provide a space for debate, meetings, and a duplicating machine. ${ }^{45}$ A typical monthly bulletin published by a world shop in the r970s included information on the shop's activities and informed readers about issues concerning the global economy and the situation of developing countries. It also acted as a forum for different local action committees, which were given room to advertise their activities and views. ${ }^{46}$

The world shops reflected a broad array of visions of a postcolonial world. More often than not, these ideas were inspired by Third World spokespersons, such as Maspéro and Prebisch, who directly and indirectly engaged with activists from the North through personal meetings, media appearances, and numerous publications. Moderate members of the movement continued to adhere to the ideals of empowering people in developing countries and in campaigns aiming to reform the structure of the global market. Compared with fair trade activists in West Germany, Switzerland, and the United Kingdom, a striking number of fair trade activists in the Netherlands adopted the rhetoric and repertoire associated with the "far left", inspired by neo-Marxist and Maoist ideas and often stressing the importance of local activism. ${ }^{47}$

Within the fair trade movement, these far left activists proposed to regard people in developing countries not as equal trading partners but as allies in a

42. Piet Reckman, Kosmokomplot 70 (Voorburg, 1970), p. 8.

43. "Wereldwinkel", Kosmodok, 3:8 (1970), p. I.

44. Ibid., pp. I-2.

45. "Landelijke vereniging van wereldwinkels - opzet wereldwinkel", Sjaloom Archive, Regionaal Historisch Centrum Zuid Oost Utrecht, I30: Stukken betreffende de Stichting Wereldwinkel te Odijk, 1970-1976.

46. See Wereldwinkelbulletin Arnhem, collection of the International Institute of Social History. 47. Gerd-Rainer Horn, The Spirit of '68: Rebellion in Western Europe and North America, 1956-1976 (Oxford, 2007), pp. I55-162. 


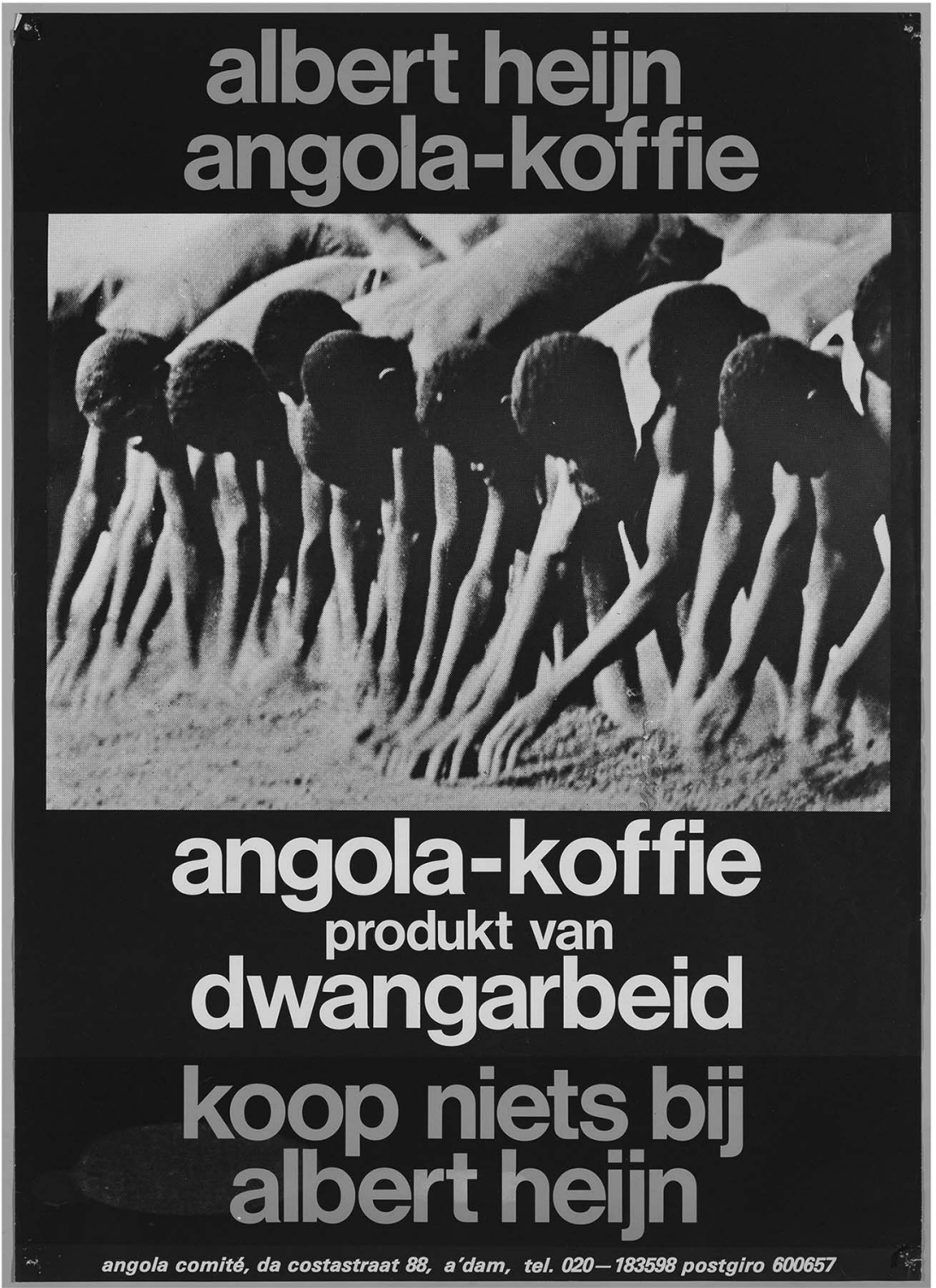

Figure I. "Albert Heijn Angola Coffee - Angola Coffee Product of Forced Labour - Do not Buy Anything at Albert Heijn”. Led by the Angola Committee, many fair trade activists supported a successful boycott against the Albert Heijn supermarket chain in 1973, because it refused to remove coffee from Angola from its shelves.

IISH Collection. 
global struggle between the rich and poor. Instead of restructuring and strengthening global interdependence to benefit developing countries, these radical activists inferred that participating in a capitalist system would inevitably lead to domination by the centre over the periphery. Building on notions of economic dependency developed by A.G. Frank, the preferred road to autonomy would be to become independent of the current economic structures..$^{48}$ Instead of reform of the global marketplace, they opted for a revolution to be led by the people of the Third World. ${ }^{49}$ These radical views gained a strong foothold in the Dutch world shop movement and among like-minded activists in West Germany, Switzerland, and the United Kingdom. ${ }^{5 \circ}$

The competing views of the aim of the fair trade movement converged in their intent to create a more equitable postcolonial world. Campaigns explicitly aiming to overcome the legacy of colonialism thus continued to comprise a significant part of fair trade activism in the Netherlands particularly. Here, arguably the most successful element was a campaign against importing coffee from Angola in 1972 and 1973. Aided by the local world shop groups, the Angola Committee distributed a flood of information asking consumers not to buy coffee from Angola because Portuguese colonizers used the profits to continue their oppression of the Angolan population. Members of world shops picketed supermarkets, distributed leaflets, posted bills and stickers, spoke to local journalists, and sold Angola-free coffee door-to-door and in their shops. ${ }^{5 \mathrm{I}}$ By the end of 1972 , most of the coffee roasters and retail companies had conceded. A second wave of protest ensued as the wellestablished supermarket chain Albert Heijn announced it would resume selling coffee from Angola in the summer of 1973 (see figure I). After a prolonged stand-off, in the autumn of that year Albert Heijn backed down, stating it had given consideration to the concern among its customers over the antagonism that had arisen regarding Angolan coffee. ${ }^{2}$

In the same year, the world shops attempted to mount a national campaign to demand a free Suriname, which was still a Dutch territory.

48. Kuitenbrouwer, Ontdekking van de Derde Wereld, pp. 23 I-233.

49. Kalter, Die Entdeckung der Dritten Welt, p. 6r; Hans Beerends and Marc Broere, De bewogen beweging. Een halve eeuw mondiale solidariteit (Amsterdam, 2004), p. 65; John Miltenburg, Van morele verontwaardiging ... tot anti-imperialisme. Aanzet tot een analyse van de Derde Wereld Beweging in Nederland (Amsterdam, 1975), pp. 57-63; Michael Ramminger and Ludger Weckel, Dritte-Welt-Gruppen auf der Suche nach Solidarität (Münster, 1997), pp. I 5-16.

50. Kuhn, Entwicklungspolitische Solidarität, p. I3; Olejniczak, Die Dritte-Welt-Bewegung in Deutschland, pp. I23-I24; Kevin O'Sullivan, "The Search for Justice: NGOs in Britain and Ireland and the New International Economic Order, I968-82", Humanity, 6:I (2015), pp. I73-I 87. 5. "Koffie-aktie. Boontje komt om zijn loontje". Koffiebulletin no. 2 Sjaloom Archive, Regionaal Historisch Centrum Zuid Oost Utrecht, i i4: Stukken betreffende de "koffie actie", I968-I972.

52. “Albert Heijn capituleert”, Nederlands Dagblad, is October 1973. 
According to the world shops magazine, Suriname provided a prime example of the way in which the centre rendered the periphery dependent: Dutch politicians decided on Suriname's political issues, Dutch companies profited from Suriname's mines, and Dutch schools and churches dominated Suriname's culture. "This has brought Suriname into an isolated position in relation to its neighbours, thereby extending Suriname's dependency on the Dutch 'motherland'." 33

In 1975, Suriname gained full independence, but this had little to do with the campaign planned by the world shops. Although many local groups had agreed to participate, their commitment was seldom translated into action. Later, they criticized the campaign's lack of information, clear objectives, and resources. Some groups also found fault with the aggressive nature of the material provided by the national federation, which left little room for debate and failed to encourage the public to reach their own conclusions. Moreover, many familiar local allies had refused to participate: churches often found the issue too politically controversial, political parties failed to respond, companies provided few opportunities for cooperation, and the local press showed little interest. This failure, all the more aggravating in its contrast to the success of the campaign for Angola, reinforced the trend towards local action. In evaluating the campaign for Suriname, members of the movement agreed that, in future, the movement would have to take its cue from the local and regional world shop groups; the national federation should confine itself to providing services to these groups. ${ }^{54}$

Debating the failure of the campaign for Suriname, very little was said about the absence of products that could be sold to support Surinamese independence. Similarly, selling Angola-free coffee had been a comparatively modest component of the pro-Angola campaign. Activists had concentrated on providing the public with information, leaving consumers to choose a brand of coffee free of Angolan coffee beans in supermarkets. The lack of focus on selling products testifies to the importance of a broader repertoire of social action in the movement for fair trade. Whereas selling products could lead to heated debates about condoning capitalist practices, other means of action were far less controversial.

Nonetheless, selling produce from developing countries remained part of the movement's repertoire, especially among the local groups, who continued to regard fair trade predominantly as a means to empower producers or as a practical and symbolic stepping stone towards a reform of the global market. Such activities gained considerable popularity across Europe during the early I970s. In 1970, ten world shops in the Netherlands joined

53. "Suriname-aksie '73", Wereldwinkel bulletin, 4:5 (1973), pp. 2-5.

54. "Evaluatie weekend I 6-I7 februari”, Ibid., 5:I (I974), p. 2; Evaluatieweekend I 6-i 7 februari. Verslag plenaire vergadering zaterdag [1974], IISH, Wereldwinkel Amstelveen Archive, Box UBA/CSD vrz 53.2: File DOS/46. 
to set up a national organization; within two years this federation had I 20 member groups. ${ }^{55}$ Similarly successful initiatives in West Germany, Belgium, Austria, and Switzerland provided SOS, the importing organization, with unexpected allies in selling the products it sourced from developing countries. ${ }^{56}$ The enormous popularity of selling products from the South caused supply shortfalls as SOS could not meet demand. ${ }^{57}$

However, the relationship between SOS and its newfound allies was hardly an easy one. Fair trade activists frequently criticized SOS's lack of explicit political objectives. A report by the federation of world shops in I 974 noted that the priorities of both organizations were similar but weighted differently. Whereas world shops aimed above all at raising political awareness in their localities, SOS stressed direct assistance to people in developing countries by selling their produce. ${ }^{58}$ To many Dutch world shop activists, the products imported by a new importing organization called Stichting Ideële Import (SII) were more attractive: SII imported goods only from countries it considered progressive because of their revolutionary leftist governments; around 1980 they included Nicaragua, Tanzania, Vietnam, Mozambique, and Algeria. ${ }^{59}$ In West Germany, Austria, and Switzerland, SOS's partners strove to loosen their ties and set up alternative import channels. ${ }^{60}$

During the second half of the I970s, however, SOS's long-time figurehead Paul Meijs was forced to step down over differences about the objectives of the organization and his style of management. The new management opted to focus on importing from producers who worked actively to change economic structures. The products also had to be useful for raising awareness in the Netherlands. SOS now framed its goals in explicitly anti-colonial terms: "During the colonial period, the West built up an enormous hegemony concerning industrialization, investment, technology, and trade, etc. This economic power is being used to perpetuate inequality and servitude", a report on its objectives stated around I980. "Therefore, SOS no longer seeks to be a force by virtue of the volume of its trade $[\ldots]$, but through the quality and the explanatory power of its activities." $^{6_{1}}$

55. Beerends et al., Anders nog iets? pp. 9-10.

56. Quaas, Fair Trade, pp. 107-108.

57. Stichting SOS aan wereldwinkeliers, 30 December 1970. Landelijke Vereniging van Wereldwinkels Archive, Ordner Externe Kontakten SOS, uittreksels '72.

58. Rapport verhouding SOS en wereldwinkels (1974). Landelijke Vereniging van Wereldwinkels Archive, Ordner Externe Kontakten SOS, uittreksels ' 72.

59. "Keuze", Ideële import informatiekrant, 5:3 (1985), p. 4.

60. Quaas, Fair Trade, pp. I08-I I 2, I47-I 52.

6r. "De doelstellingen van SOS-Wereldhandel en de ontwikkeling ervan" [1980]. Landelijke Vereniging van Wereldwinkels Archive, Ordner Produktenwerkgroep Koffie SOS, Korrespondentie en kontrakten SOS, diversen. 


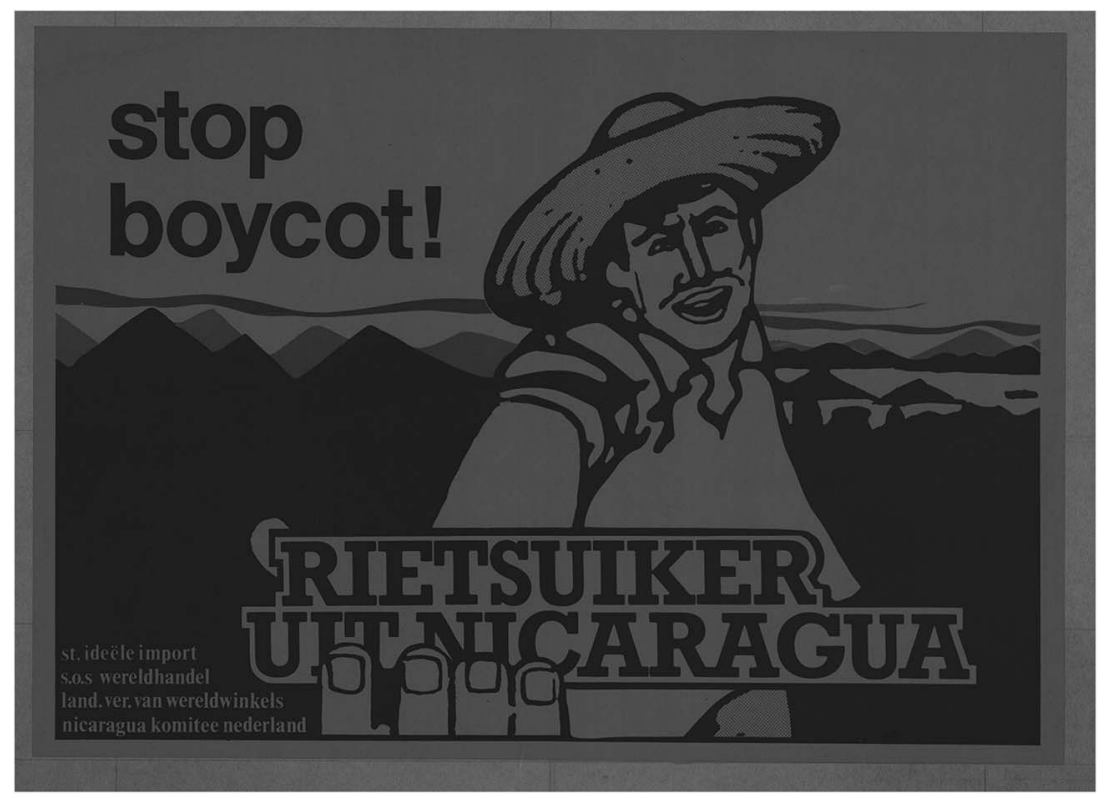

Figure 2. "Stop Boycott - Cane Sugar From Nicaragua". During the late I980s, a coalition of Stichting Ideële Import, SOS the National Federation of World Shops, and the committee for solidarity with Nicaragua (Nicaragua Komitee Nederland) called on consumers to buy cane sugar from Nicaragua in order to mitigate the effect of international trading embargos against the country.

IISH Collection.

The increased availability of products that could be sold to support "progressive" countries and movements made selling a much more attractive strategy, especially for far-left world shop groups, which had previously had reservations about selling. This gradual shift within the fair trade movement mirrored the slow disintegration of notions of a unified Third World during the 1970s. After the independence of most of those countries that had identified themselves as being part of the Third World, the focus had shifted from political to economic independence. At the same time, the political intervention by the oil-producing countries had drawn attention to differences within the Third World. ${ }^{62}$ European radicals reacted by adopting two strategies to support revolutionary politics. On the one hand, they could offer practical support to revolutionary governments and movements in the Third World, as many world shop groups did (see figure 2). ${ }^{63}$

62. Kalter, Die Entdeckung der Dritten Welt, pp. $65-70$.

63. Robert Gildea, James Mark, and Niek Pas, "European Radicals and the 'Third World': Imagined Solidarities and Radical Networks, I958-73", Cultural and Social History, 8 (20I I), pp. 449-47I, 47I. 
Others continued to focus on transforming their own immediate environment, often expanding the range of issues with which they were concerned well beyond the immediate concerns of Third World countries.

Attempting to unite those focused on developing countries and those preoccupied with changing their own environment, "liberation" proved a keyword that could unite the fair trade movement in the early ig8os. "Working towards liberation" was the motto of the congress celebrating fifteen years of world shops in 1984. "Those trodden upon are organizing. We take up their call, we organize ourselves, and liberation becomes more than a word", participants in the congress read in the congress papers they were provided with. ${ }^{64}$ While the incentive to change the world still came from those in less-privileged circumstances, those participants could observe a wide range of activities by the world shops, which focused on liberation within their own environment. The struggle of women for autonomy had become an important issue, for example. The world shop women, who had always made up the majority of the movement, now came consciously to the fore: they struggled for the rights of their fellow women abroad, for equal treatment at home, but also for disarmament and the rights of migrants, just as they intended to fight racism and fascism. ${ }^{65}$

\section{ADAPTING THE WRAPPING (1984-1997)}

During the I980s and I990s, notions of a postcolonial order dominated by nations or by three separate "worlds" were gradually replaced by a notion of "global citizenship". Development was no longer located in nations moving towards Western modernity or self-reliance in unison, or marked by three worlds in which hope for change lay with the Third World. ${ }^{66}$ According to Frederick Cooper, this rise of "global citizenship" implied the insistence "that all people, by virtue of their humanity, are entitled to have their basic needs met" and a negligence of state sovereignty. ${ }^{67}$ However, not everyone was equal in this new vision of the global marketplace. As other categorizations moved into the background, the opposition between a consuming North and a producing South became the main axis around which fair trade activism was constructed.

The notion of a North-South divide signalled the rise of a less radical political approach to the postcolonial world. It did not tap into the

64. Werken aan bevrijding, Kongresmap Is jaar wereldwinkels (1984), Landelijke Vereniging van Wereldwinkels Archive, Ordner Produktenwerkgroep Koffie SOS, Korrespondentie en kontrakten SOS, diversen.

65. Ibid.

66. Mark Berger, "After the Third World? History, Destiny and the Fate of Third Worldism”, Third World Quarterly, 25 (2004), pp. 9-39.

67. Frederick Cooper, "Writing the History of Development", Journal of Modern European History, 8: I (2010), pp. 5-23, I7. 
supposed transformative potential of a Third World, but instead highlighted an unjustifiable global inequality. To be sure, fair trade activists did not accept the structure of the existing global market. Instead of attempting a revolution, they now largely agreed that a postcolonial world could be achieved through empowerment and gradual reform. In parallel with many other social movements, they adopted a more incremental and pragmatic approach. ${ }^{68}$ Several factors contributed to this. First, partners from the South, such as the Nicaraguan government and cooperatives such as the Mexican UCIRI, pressed their relations in the North to move beyond symbolic support. In order to sustain their existence, the revenues through sales would have to be increased. ${ }^{69}$ Disillusionment with the achievements of radical politics at home and in "distant paradises" fuelled this reorientation. ${ }^{70}$ As many right-wing politicians came to power during the I 980 s, the need to cooperate in the face of a common adversary was more urgently felt among the left. Moreover, the hope for a successful grand design to achieve global development waned in the I980s, in which the failures of past attempts at development were widely recognized and talk of a "lost decade" proliferated. ${ }^{71}$

Regarding the historiography of fair trade, the popularity of a more pragmatic approach has led observers to assert the occurrence of a watershed in its history during the 1980 . The watershed was purportedly marked by a sudden transformation of the movement from "alternative trade" to a more mainstream-oriented "fair trade". This suggestion discards the long tradition of mainstream-oriented trade and the many attempts to reach the general public. It also ignores the persistence of many of the practices developed by the movement. ${ }^{72}$ Selling products had been a continuous - if often contested practice within the movement, which shifted gradually into the foreground as activists predominantly favoured more pragmatic approaches.

"The message the shops are propagating has stayed the same, but the wrapping will have to be adapted to the spirit of the times", wrote a member

68. Eleanor Davey, "French Adventures in Solidarity: Revolutionary Tourists and Radical Humanitarians", European Review of History: Revue Européenne d'Histoire, 2 I (2014), pp. 577-595.

69. Quaas, Fair Trade, pp. I 8 I-267; Gavin Fridell, Fair Trade Coffee: The Prospects and Pitfalls of Market-Driven Social Justice (Toronto, 2007), pp. 173-1 83; Frans VanderHoff Boersma, "Poverty Alleviation through Participation in Fair Trade Coffee Networks: The Case of UCIRI, Oaxaca, Mexico", available at: http://cfat.colostate.edu/wp-content/uploads/2009/og/Case-StudyUCIRI-Oaxaca-Mexico.pdf, last accessed 25 February 2015.

70. Julian Bourg, From Revolution to Ethics: May 1968 and Contemporary French Thought (Montreal, 2007); Aart Aarsbergen, Verre paradijzen. Linkse intellectuelen op excursie naar de Sovjet-Unie, Cuba en China (Utrecht, 1988).

71. Olav Stokke, The UN and Development: From Aid to Cooperation (Bloomington, 2009), pp. 315-320.

72. Van Dam, "The Limits of a Success Story". 
of staff of the World Shop Association in 1986, soothing anxiety over a feared loss of political vigour resulting from an approach aimed at increasing turnover. ${ }^{73}$ Like earlier developments within the movement, the transformation was shaped by transnational exchanges. In 1987, a congress of European world shops debated the issue of professionalization extensively. Representatives told of their attempts to hire permanent staff, adjust the opening hours of the shops to those of shops around them, and expand the selection of products to include more daily necessities. Most participants from across Europe agreed that a more professional approach was feasible, but they also feared such an approach could compromise their aims, not just by playing to the tune of the market, but also because it put pressure on the democratic structures of their organizations. Moreover, it was more expensive, reinforcing the need to increase the turnover of the shops. ${ }^{74}$ Despite these doubts, a majority of the world shop groups in the Netherlands apparently endorsed this new course. ${ }^{75}$

Solidaridad, the Dutch Catholic development organization for Latin America, was an influential driver of attempts to increase the impact of fair trade. In 1985 , it pioneered a campaign to address the partial responsibility of Dutch banks for the debt crisis in Latin America. Rather than promoting "alternative banking", Solidaridad urged customers to donate part of their earned interest to an "interest solidarity fund" and to write to the board of directors of their banks, urging them to reconsider their policies. Although alternative banking could provide a "sign of hope", meaningful change would come about only if large companies also changed their ways, Solidaridad's staff argued. ${ }^{76}$

Solidaridad opted for a similar approach in addressing world hunger in a campaign launched in 1986. Publicizing how Northern companies and governments contributed to the agricultural crisis in the South, they also attempted to provide local activists with tangible alternatives. ${ }^{77}$ To this end,

73. Adriaan Horrevoets, "Kanttekeningen bij de aanbevelingen aan de LaVe van het congres. Wereldwinkelcongres 8 november 1986", Landelijke Vereniging van Wereldwinkels Archive, Ordner Algemeen bestuur jaren I985-1986.

74. "Europees congres wereldwinkels", Ontzet, i8:8 (1987), pp. 3-5; "Verslag workshop 'Professionalisierung' tijdens de internationale bijeenkomst van Wereldwinkels in Keulen” [1987]. Landelijke Vereniging van Wereldwinkels Archive, Ordner Externe kontakten Internationale Bijeenkomsten tot I99I, I8.I.

75. "Uitslag van de enquête gehouden door de ww's Zetten en Elst n.a.v. het congres van I6 januari jl.", Landelijke Vereniging van Wereldwinkels Archive, Ordner Zuivere Koffie tot november' 88 .

76. “Actiewijzer Solidaridad-kampagne 1985 'Onze rente, hun armoede”. Katholiek Documentatie Centrum [hereafter: KDC], Solidaridad Archive, I40, Stukken betreffende acties, 1975-1988.

77. "Aan de betrokkenen bij de kampagne 'Zuivere koffie, een kwestie van smaak'”, Ibid., I 40, Stukken betreffende acties, I975-1988; Ibid., I4I, Stukken betreffende acties, 1975-I988. 


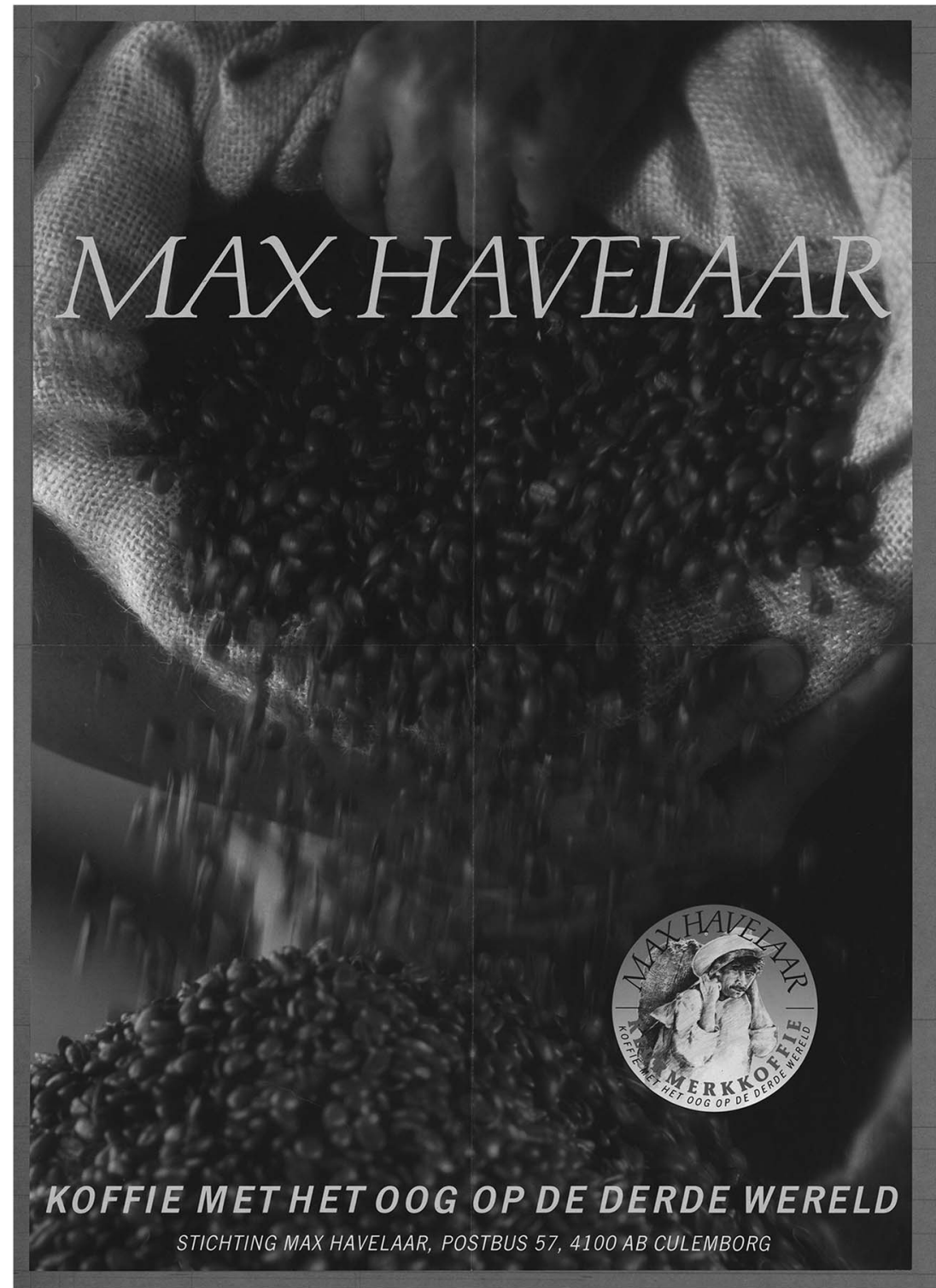

Figure 3. "Max Havelaar - coffee with an eye to the Third World". The Max Havelaar label for fair trade coffee was introduced in 1988 in order to expand the sales of fair trade coffee. Consumers were called on to make a difference for producers by taking the Third World into consideration during their daily supermarket shopping.

IISH Collection. 
coffee was deemed a suitable product. After initially encouraging activists to sell fair trade coffee provided by importers such as SOS, Solidaridad considered introducing a new brand of coffee on the market as a way to achieve a bigger impact. ${ }^{78}$ During negotiations with potential partners, they realized that it would be more feasible to introduce a fair trade label for coffee, which any retail organization could obtain if it adhered to the standards set by the label. ${ }^{79}$ The initiative explicitly referred to overcoming a colonial condition by choosing as its name "Max Havelaar", the eponymous protagonist of the book published in I 860, who denounced the colonial practices of the Dutch in the East Indies (see figure 3 ). ${ }^{80}$

After the successful introduction of Max Havelaar coffee on the Dutch market, the world shops took stock at the start of the i 990 os. The professionalization of fair trade had been welcome, a report concluded. Trade had always been a staple of the movement, but its members had not always taken it as seriously as they should have. The pragmatic approach to fair trade had helped the movement to move from the margins and to establish more productive relations with ecological groups, consumer organizations, and other development activists. ${ }^{8 \mathrm{r}}$ As in West Germany, the movement loosened its ties with what Sven Reichardt has dubbed "the alternative milieu", broadening the scope of potential partners and customers. ${ }^{82}$ It also strengthened its transnational ties. Since 1987 , activists from all over the world met regularly at the initiative of the International Federation for Alternative Trade (IFAT). In the same year, European importing organizations established their own network, the European Fair Trade Association (EFTA), which aimed to improve cooperation between European alternative trading organizations by sharing resources and information, coordinating relations with Southern partners, and providing a stronger joint presence on the European and international political stages. More intra-European cooperation would allow the trading organizations to operate more professionally. ${ }^{83}$

78. Nico Roozen, "Notitie voor de evaluatie van de kampagne 'Zuivere koffie, een kwestie van smaak', najaar I986 en een voorzichtige vooruitblik, januari 1987”, Ibid., 74, Notulen van het Aktiekomitee Solidaridad, 1970-1986.

79. "Staf Solidaridad aan Algemeen Bestuur Solidaridad. Onderzoeksrapport haalbaarheid publieksmerk 'zuivere koffie', 27 augustus 1987”, Ibid., 297, Agenda's voor en verslagen van vergaderingen van het algemeen bestuur (AB), I986-1999; "Zuivere koffie met het oog op de derde wereld: 'Ideële handel mag niet symbolisch blijven”, Ibid., I44, Stukken betreffende acties, I975-1988.

80. Multatuli (pseud. Eduard Douwes Dekker), Max Havelaar, Of de koffiveilingen der Nederlandsche Handelsmaatschappy (Amsterdam, I860).

8 I. Landelijke Vereniging van Wereldwinkels, Perspectief voor de jaren negentig, personal archive Henk Morel, Wereldwinkel Amstelveen.

82. Sven Reichardt, Authentizität und Gemeinschaft. Linksalternatives Leben in den siebziger und früben achtziger Jahren (Berlin, 2014); Quaas, Fair Trade, pp. 254-265.

83. Marlike Kocken, "Proposal for set-up of federation, June 1987", European Fair Trade Association Archive, documents concerning the founding of the EFTA. 
The outlook of the European fair trade movement had thus become more focused during the I980s. The 1984 congress of Dutch world shops had combined a wide array of activities and interests into a struggle for "liberation", which was conducted at home and abroad. Since the second half of the I980s, fair trade activists returned to a more exclusive focus on development. Within this new approach, world shops were seen primarily not as local campaigning centres but as shops where customers could buy fair trade products. Paradoxically, as a result of this gradual shift the individual consumer became at once more and less important. The more professional strategy and the deliberate attempts to raise sales figures on behalf of Southern producers meant that the consumer became a more central figure in the ways in which fair trade was envisioned. At the same time, consumers were no longer expected to become activists themselves. The individual motives of consumers in buying fair trade products mattered less than the aggregate value of products they were buying. ${ }^{84}$ Increasing sales figures not only crucially strengthened producers, these figures also became an important tool in the hands of intermediary fair trade organizations. Continuing their attempts to lobby politicians and raise awareness of global inequality, they could serve to support their claim that citizens were voting for fair trade with their purses. ${ }^{85}$

The professionalization of world shops and the new possibility of labelling individual products as "fair" resulted in a gradual rapprochement with regular market parties after the i980s. As fair trade organizations attempted to enhance their impact and expand the range of fair trade products, this alliance gained in significance. Once different national labelling initiatives had set aside their differences and founded the Fairtrade Labelling Organization (FLO) in I997, the relationship with large companies became the primary bone of contention within the movement. ${ }^{86}$ The definition of fair trade standards, the monitoring of compliance, and the admission of plantations to a fair trade system geared towards small producers were all fiercely contested. Following a broader trend towards emphasizing corporate social responsibility, attempts to arrive at an equitable postcolonial world incorporated the transformation of multinational companies along with changing market regulations and empowering producers. This trend changed the face of fair trade in Europe. Whereas world shops retained a strong presence especially in Germany, the Netherlands,

84. The stress on the importance of selling and marketing also fuelled critiques of the consumption of fair trade products being less a moral choice than a way for well-off citizens to distinguish themselves by buying "good" products. Kathryn Wheeler, Fair Trade and the Citizen-Consumer: Shopping for Justice? (Basingstoke, 20 I 2), pp. I I I-I 40.

85. Ibid.

86. Elisabeth Bennett, "A Short History of Fairtrade Certification Governance", in Brigitte Granville and Janet Dine (eds), The Processes and Practices of Fair Trade: Trust, Ethics, and Governance (London, 2013), pp. 53-78. 
and Italy, companies selling fair trade products through regular retail channels became influential new players in the field. ${ }^{87}$

\section{CONCLUSION: THE DEMISE OF THE POSTCOLONIAL CONSUMER SOCIETY?}

Ever since the first fair trade initiatives of the I960s, people around the world were urged to position themselves within a postcolonial world. Explicit appeals to the legacy of colonialism gradually lost forcefulness as the process of decolonization slowly slid away into the past. Nonetheless, designations such as "Max Havelaar" and appeals to overcome the legacy of colonial inequality have continued to convey an explicitly postcolonial perspective. Moreover, during the postwar era the interests of the South have persistently been subordinated to the construction of consumer societies in the North. Fair trade supporters have accordingly continued to define economic inequality predominantly in geographical terms, stressing the disadvantaged position of producers in formerly colonized countries.

The history of the fair trade movement thus underlines the importance of a postcolonial perspective on postwar history beyond the history of international affairs, migration, and literature. Such a perspective renders visible the influence of decolonization on the daily life of people across the globe, influencing among other things the debate on the morality of consumer society and the relationship between consumers and producers in a globalized economy. As has been demonstrated above, fair trade history brings shifting visions of a postcolonial world and the different strategies deployed to achieve them into focus. It demonstrates how decolonization caused a shift in the balance of spatial frames of reference - local, national, European, Western, etc. - in which individual actors operated. During the I960s, geopolitical blocs (First-, Second-, and Third World) were the main point of departure for activists, who predominantly argued for reforms and empowerment of producers. As radical activists gained a strong foothold within the movement during the I970s, these were complemented by individual nation states that had to be supported by trade or counteracted through boycotts. After the I980s, radical politics were in retreat. The frameworks of geopolitical blocs and "good" and "bad" nations were supplanted by a global opposition between the South and the North, and accompanied by a preoccupation with local producers.

Equally, strategies evolved over time. Owing to the diverse coalition of activists united around the issue of fair trade, the movement was continually ambivalent about the uses of consumer activism and possible 
alternative means. Initiatives during the I960s were divided between attempts to exert political pressure for reforms and the economic empowerment of producers in developing countries. During the I970s and early I980s, these strategies were accompanied by efforts to support revolutionary groups and to transform the local environment as part of a more radical challenge to the global economy. After the I980s, a more pragmatic approach aiming at incremental transformation and professional campaigns evolved. Whereas during the I960s and I970s national governments and international bodies were deemed primarily responsible for establishing a more equitable world, by the I 980 s all actors involved in the market were deemed equally responsible.

In recent years, it appears as though the postcolonial framework is gradually being replaced by a more radical interpretation of global citizenship. The postcolonial framework had stressed the difference between North and South or between First- and Third World and equated this divide with the distinction between consumers and producers. As current campaigns are directed towards changing the behaviour of all actors involved in the market, fair trade standards are increasingly applied to actors in the North. In stressing corporate social responsibility, companies are expected to take social and ecological concerns into account in the North as well as in the South. Similarly, the internationally proliferating "fair trade towns" campaign encourages local communities to identify themselves with "fair" principles. ${ }^{88}$ Fair trade marketing appeals to individual consumers to consider the ethics of their buying decisions. In this sense, fair trade is "bringing the moral charge home" ${ }^{89}$ Paradoxically, the demise of an explicitly postcolonial perspective may thus enhance the impact of the ideas and practices historically promoted by the fair trade movement. Attempts to arrive at an equitable postcolonial world may have unexpectedly contributed to the discovery, or rediscovery, of a frame of reference that empowers demands for economic justice for people closer to home.

\section{TRANSLATED ABSTRACTS \\ FRENCH - GERMAN - SPANISH}

Peter van Dam. En moralisant la société de consommation postcoloniale. Le commerce équitable aux Pays-Bas, 1964-I997.

La décolonisation a mis au défi des gens dans le monde entier de définir leur place dans un régime postcolonial. Ce défi a été ressenti dans les affaires internationales

88. Available at: http://www.fairtradegemeenten.nl/algemeen/over-fairtrade-gemeente/, last accessed ${ }_{4}$ April 2014; Wheeler, Fair Trade and the Citizen-Consumer, pp. 55-84.

89. Daniel Jaffee, Jack R. Kloppenburg jun., and Mario B. Monroy, "Bringing the 'Moral Charge' Home: Fair Trade within the North and within the South", Rural Sociology, 69 (2004), pp. 169-196. 
politiques et économiques, mais il a également affecté des vies quotidiennes dans tous les pays. L'histoire de l'activisme du commerce équitable, vue à partir des Pays-Bas, illustre comment des citoyens au Nord se sont débattus pour se positionner dans une société de consommation postcoloniale. Les interventions des activistes du commerce équitable ont raccordé les débats sur la moralité de leur société aux conséquences de la décolonisation. Ils ont réagi aux déséquilibres du marché mondial dus à la décolonisation, rejoignant les critiques dans le Sud exigeant des relations mondiales plus équitables. C'est autour de cette question du "commerce équitable" qu'une coalition transnationale d'activistes modérés et plus radicaux est apparue après les années 1960. Cette coalition avait des opinions extrêmement différentes concernant la politique de la gauche et l'utilisation de l'activisme des consommateurs. L'analyse de leurs interventions démontre que pendant l'ère de l'après-guerre, les tentatives pour transformer le marché mondial et des visions d'un ordre postcolonial étaient inextricablement imbriquées les unes dans les autres.

Traduction: Christine Plard

Peter van Dam. Die Moralisierung der postkolonialen Konsumgesellschaf. Fair Trade in den Niederlanden, $1964-1997$.

Die Dekolonisierung hat Menschen in aller Welt vor die Herausforderung gestellt, in der neuen postkolonialen Ordnung ihren Platz zu finden. Diese Herausforderung machte sich in internationalen politischen und wirtschaftlichen Angelegenheiten bemerkbar, doch sie wirkte sich auch weltweit auf das Alltagsleben aus. Die Geschichte des FairTrade-Aktivismus, wie sie sich aus niederländischer Perspektive darstellt, zeigt, wie die Bürger des globalen Nordens darum rangen, sich in einer postkolonialen Konsumgesellschaft $\mathrm{zu}$ positionieren. Die Interventionen von FairTrade-Aktivisten stellten einen Zusammenhang her zwischen Debatten um die Moral der eigenen Gesellschaft und den Folgen der Dekolonisierung. Die Aktivisten reagierten auf die Ungleichgewichte des Weltmarktes im Gefolge der Entkolonialisierung und unterstützten die Forderung von Kritikern aus dem globalen Süden nach gerechteren internationalen Beziehungen. Um die Frage des "fairen Handels" bildete sich nach den I960er Jahren ein Bündnis moderater und radikalerer Aktivisten. Innerhalb dieses Bündnisses waren sehr unterschiedliche Ansichten zur Politik der Linken und zum Repertoire des Verbraucheraktivismus anzutreffen. Die Analyse der betreffenden Interventionen zeigt, dass Bemühungen um die Transformation des Weltmarktes in der Nachkriegszeit untrennbar verwoben waren mit Visionen einer postkolonialen Ordnung.

Übersetzung : Max Henninger

Peter van Dam. Moralizando la sociedad de consumo postcolonia. El comercio justo en los Países Bajos, 1964-I997.

La descolonización supuso un desafío para todo el mundo en un nuevo orden postcolonial. Este reto se sintió de forma especial en la política internacional y en los asuntos económicos, pero también llegó a incidir en la vida cotidiana de la gente en 
cualquier lugar del planeta. La historia del activismo por un comercio justo vista desde los Países Bajos pone de relieve como los ciudadanos en el Norte pugnaban por posicionarse en una sociedad de consumo postcolonial. Acciones llevadas a cabo por activistas por el comercio justo pusieron en conexión debates sobre la moral de su sociedad en relación con las consecuencias de la descolonización. Reaccionaron frente a los desequilibrios del mercado global generados por las secuelas de la descolonización, uniéndose a las críticas procedentes del Sur reivindicando unas relaciones globales más equitativas. Fue alrededor de la cuestión del "comercio justo" que emergió una coalición transnacional de activistas, que incluía desde los moderados a los más radicales, después de la década de i960. Esta coalición mantuvo puntos de vista muy dispares en lo referente a la política de la izquierda y al uso consumo como una herramienta activista. El análisis de sus intervenciones permite demostrar que durante la época de postguerra, los intentos de transformar el mercado global estaban inextricablemente entrelazados con las visiones del orden postcolonial. 